\title{
Nacechowanie emocjonalne deminutywów - semantyka czy pragmatyka?
}

\section{Wstęp}

Deminutywa najczęściej są definiowane jako wyrazy pochodne, powstałe wskutek dodania odpowiedniego formantu. Oznaczają one zazwyczaj przedmiot mniejszy w stosunku do przedmiotu opisywanego przez wyraz podstawowy. Często w definicjach wspomina się, że deminutywa mogą mieć zabarwienie emocjonalne dodatnie. Zdecydowanie rzadziej pojawiają się wzmianki, iż mogą być także nacechowane ujemnie. Źródła z reguły skupiają się na słowotwórstwie: wymieniają formanty uczestniczące $\mathrm{w}$ tworzeniu deminutywów, podają obostrzenia co do potencjalnych wyrazów podstawowych oraz zaobserwowane oboczności. $\mathrm{Z}$ reguły opisy znaczenia zdrobnień pojawiające się $\mathrm{w}$ literaturze są $\mathrm{w}$ dużym stopniu uproszczone. Należy zaznaczyć, że biorąc pod uwagę tradycyjne postrzeganie deminutywów, należałoby sklasyfikować je jako wyrażenia nieostre - z uwagi na to, że opisują rozmiar, ale też polisemiczne o co najmniej dwóch podstawowych znaczeniach - małości i nacechowaniu emocjonalnym.

Niezgodne z prawdą byłoby jednak stwierdzenie, że kwestia pragmatycznych znaczeń deminutywów została całkowicie zignorowana. Jednym z celów niniejszej pracy jest ukazanie, w którym miejscu językoznawcy przeprowadzają podział między semantycznymi i pragmatycznymi znaczeniami zdrobnień, ze szczególnym uwzględnieniem pozytywnego i negatywnego nacechowania emocjonalnego. Przedmiotem analizy są trzy podejścia wybrane z literatury obcojęzycznej. Pierwsze z nich to ujęcie zaproponowane przez Bronislavę Volek (1987; 1990), poświęcone użyciu zdrobnień w języku rosyjskim, traktujące deminutywa jako znaki emotywne (emotive signs). Drugie podejście to ujęcie morfopragmatyczne Wolfganga Dresslera i Lavinii Merlini Barbaresi (1994), opisujące głównie

* Katedra Filologii Angielskiej, Uniwersytet Mikołaja Kopernika w Toruniu, ul. Bojarskiego 1, 87-100 Toruń. 
deminutywa $\mathrm{w}$ językach włoskim i niemieckim. Jednym z celów przyświecających autorom jest sprawdzenie wcześniejszego rozwiązania, w którym deminutywa są postrzegane jako modyfikatory aktów mowy (speech acts modifiers) (Bazzanella, Caffi i Sbisà 1991). Ostatnie z podejść to ujęcie formalno-funkcjonalne (formal-functional approach) zaprezentowane przez Klausa Schneidera (2003) w monografii poświęconej deminutywom w języku angielskim, w tym ich użyciu w codziennej komunikacji. Wnioski płynące z zaproponowanych przez autorów klasyfikacji wykorzystane są przy rozważaniach dotyczących tego, gdzie należałoby upatrywać rozgraniczenia między semantycznymi i pragmatycznymi znaczeniami deminutywów i czy jest ono w ogóle możliwe. Natomiast zasadniczym celem niniejszego rozdziału jest próba odpowiedzi na bardziej ogólne pytanie: czy możliwe jest definitywne rozgraniczenie pomiędzy semantyką i pragmatyką.

\section{Pragmatyczne i semantyczne podejście do polisemii}

Przed omówieniem źródeł językoznawczych należy zwrócić uwagę na dwa podstawowe teoretyczne podejścia do klasyfikowania znaczeń wyrażeń języka naturalnego. Pierwszym $\mathrm{z}$ nich jest podejście pragmatyczne propagowane przez Paula Grice'a i jego zwolenników. Polega ono na uznaniu, że słowo zwykle ma jedno podstawowe znaczenie wspólne dla wszystkich jego użyć (simple and unitary sense). To, co zmienne i zależne od kontekstu, należy do warstwy pragmatycznej znaczenia, innymi słowy jest to zbiór uogólnionych implikatur konwersacyjnych. Alternatywę dla podejścia pragmatycznego stanowi podejście polisemiczne, nazywane też semantycznym, w którym semantyce przyporządkowuje się różne znaczenia danego słowa. Takie podejście ma jednak zasadniczą wadę, gdyż doprowadza do zatarcia podziału między tym, co semantyczne i tym, co pragmatyczne, a w rezultacie do przeświadczenia, że znaczenie słowa nie istnieje poza kontekstem (Grudzińska 2011).

Semantyczne podejście do polisemii prowadzi do problemów teoretycznych, usystematyzowanych w przeglądowym artykule Justyny Grudzińskiej (2011). Autorka zwraca uwagę na problem rozróżnienia między polisemicznością a niezdeterminowanym znaczeniem wyrażeń (generality, indeterminacy) (2011: 274-276). Polisemia zachodzi, gdy poszczególne znaczenia wyrażenia można wyróżnić, ale są one ze sobą pod jakimś względem związane, np. koło - „część płaszczyzny ograniczona okręgiem”, koło - „część pojazdu o kształcie koła umożliwiająca jego ruch". Wyrażenia polisemiczne odznaczają się tym, że pewne aspekty ich znaczenia są wspólne wszystkim użyciom danego wyrażenia, stanowiąc jego podstawową strukturę semantyczną (underlying semantic structure). Natomiast ogólność znaczenia polega na braku sprecyzowania co do jakiejś cechy. Wyrażenia polisemiczne wchodzą $\mathrm{w}$ inną relację $\mathrm{z}$ kontekstem niż wyrażenia ogólne. Kontekst aktywuje jedno ze znaczeń wyrazu wieloznacznego, inaczej rzecz 
się ma z wyrazami o znaczeniu ogólnymi, których sens jest doprecyzowywany w zależności od kontekstu (Grudzińska 2011: 275). Istniejące testy diagnostyczne na rozróżnienie między polisemicznością a ogólnością (niezdeterminowaniem) nie dają satysfakcjonujących i jednoznacznych odpowiedzi (Geeraerts 1993; Grudzińska 2011). W rezultacie Grudzińska stwierdza, że nie istnieje operacyjna definicja polisemiczności (2011: 276).

Chcąc rozwiązać dylemat, czy polisemia powinna być klasyfikowana jako zjawisko semantyczne, czy pragmatyczne, Grudzińska przechodzi do omówienia czterech zasadniczych różnic między zjawiskami semantycznymi i pragmatycznymi.

Po pierwsze, znaczenia semantyczne są konwencjonalne i stałe we wszystkich kontekstach, podczas gdy znaczenia pragmatyczne zmieniają się w zależności od kontekstu. Autorka zauważa jednak, że porównania między poszczególnymi słownikami oraz eksperymenty z użytkownikami języka wskazują na to, że nie ma zgody co do umiejscowienia podziałów między poszczególnymi znaczeniami w sferze semantycznej wyrazów polisemicznych (2011: 277).

Po drugie, znaczenia konwencjonalne są charakterystyczne dla danego języka, natomiast znaczenia pragmatyczne opierają się na mechanizmach ogólnych, można zatem oczekiwać, że są uniwersalne. Tutaj Grudzińska wskazuje na fakt, że można znaleźć polisemiczne słowa pochodzące z różnych języków, które mają odpowiadające sobie zbiory znaczeń, jak angielskie crawl i francuskie ramper (2011: 278).

Po trzecie, zjawiska semantyczne są arbitralne i nieprzewidywalne, a zjawiska pragmatyczne - umotywowane i przewidywalne. Autorka podkreśla, że polisemia podlega zwykle procesom motywującym, które są produktywne, poddają się regułom, są przewidywalne i występują w wielu językach, jak rzutowanie metonimiczne czy metaforyczne (2011: 278).

Po czwarte, wieloznaczność semantyczna jest ograniczona co do liczby alternatyw. Innymi słowy, z teoretycznego punktu widzenia zbiór semantycznych znaczeń danego słowa jest określony i skończony, natomiast znaczenia pragmatyczne są do pewnego stopnia niezdeterminowane. Tu Grudzińska zauważa, że semantyczne podejście do polisemii prowadzi do niekończącego się procesu przyrostu liczby znaczeń, co świadczy o pragmatycznej naturze tego zjawiska (2011: 280). Jako przykład podaje czasownik run (biegać), który w słowniku Webstera ma 29 znaczeń podzielonych na prawie 125 podznaczeń.

Autorka kończy artykuł stwierdzeniem, że uznanie polisemii za zjawisko semantyczne, a nie pragmatyczne, nie jest uzasadnione, ponieważ nie pozwala na zachowanie podziału między semantyką i pragmatyką (2011: 280-281). Co więcej, prowadzi do przeświadczenia, że nie istnieje coś takiego, jak znaczenie słowa poza konkretnym kontekstem. Obserwacje i wnioski poczynione przez Grudzińską (2011) posłużą jako teoretyczna podstawa do analizy prac językoznawczych poświęconych deminutywom. 


\section{Deminutywa w semantyce emotywnej}

Jako pierwsze omówione zostanie podejście autorstwa Bronislavy Volek, przedstawione w książce jej autorstwa (1987) i podsumowane w późniejszym artykule (1990). Volek bada znaczenia deminutywów w podejściu nazwanym semantyką emotywną, przyjmując założenia strukturalno-funkcjonalne szkoły praskiej.

Autorka krytykuje dominującą w językoznawstwie opinię, że emotywność to zjawisko marginalne w języku (1987: 1-2). Jej zdaniem emotywność przenika praktycznie całą komunikację językową (1987: 3). Język jest superstrukturą, obejmującą heterogeniczne podsystemy, między którymi zachodzą różnego rodzaju połączenia podczas każdego użycia, tworzące unikalną hierarchiczną strukturę powierzchniową (1987: 3). Volek uważa, że emotywność jest osobnym podsystemem w systemie języka (1987: 3).

Na podstawie tego założenia, autorka definiuje pojęcie znaku emotywnego (emotive sign). Przez znak Volek rozumie każdy element języka służący przekazywaniu informacji, który jest definiowalny jako jednostka (definable in terms of units) na każdym poziomie języka lub też jako jednostka utworzona w tekście poprzez akt mowy (1987: 219). Znaki emotywne są to znaki specjalnie przystosowane, aby przekazywać treści emotywne (1987: 25).

Volek postrzega emotywność w języku głównie jako zjawisko semantyczne, tzn. zbiór składników semantycznych szczególnego rodzaju (complex of semantic components of a special kind) (1987: 25). Składniki te mogą być wyrażone na różnych poziomach języka: fonologicznym, morfologicznym, leksykalnym, składniowym, a nawet suprasegmentalnym (1987: 14). Autorka podkreśla, że głównymi dla podsystemu emotywnego są właśnie te środki językowe, które służą bezpośredniemu wyrażaniu stosunku emocjonalnego mówiącego i które są zarazem znakami specjalnie przystosowanymi do wyrażania emocji w danym języku (1987: 12).

Choć Volek jest zainteresowana znakami emotywnymi jako takimi, duża część książki została poświęcona rosyjskim deminutywom rzeczownikowym utworzonym na drodze sufiksacji. Ich znaczenie jest badane w oparciu o korpus zawierający głównie rosyjską prozę i dramaty, przede wszystkim z lat sześćdziesiątych XX wieku.

Volek uznaje, że zdrobnienia mają dwa komponenty znaczeniowe występujące osobno bądź równocześnie: komponent ilościowy Qt (quantifying meaning component) oraz komponent jakościowy Exc (qualifying meaning component albo excitizer) (1987: 145). Należy zaznaczyć, że Volek zawsze analizuje znaczenie zdrobnień w kontekście, przypisując im opis złożony z pary symboli Qt i Exc. Symbol Qt może być oznaczony indeksem S, żeby wskazać na mały rozmiar desygnatu, bądź L, wskazującym na duży rozmiar desygnatu, co jednak 
w przypadku deminutywów jest niezwykle rzadkie. Komponent jakościowy to komponent emotywny znaczenia, komunikowany w sposób bezpośredni i z reguły zamierzony (1987: xi; 9). W przypadku zdrobnień uszczegóławia się go w zależności od wyrażanej oceny poprzez dodanie indeksów: Ev+ (nacechowanie pozytywne), Ev- (nacechowanie negatywne), $\mathrm{Ev} \pm$ (nacechowanie ambiwalentne).

Analiza pragmatyczna przeprowadzona przez Volek opiera się na ustaleniu, jak zdrobnienia mają się do nadawcy wypowiedzi i jej adresata. W głównej mierze polega to na identyfikacji bodźców, które spowodowały wystąpienie nacechowania emocjonalnego oraz opisie tego, jak to nacechowanie jest odzwierciedlone w języku. Należy podkreślić, że Volek nie odwołuje się do żadnej konkretnej teorii aktów mowy.

Na podstawie korpusu autorka zauważa, że bodziec do wystąpienia stosunku emocjonalnego u nadawcy może być nazwany w wypowiedzi, ale może nim być też jej adresat. Co więcej, sufiksy deminutywne wydają się mieć wyjątkową cechę wyrażania stosunku emocjonalnego mówiącego zarówno do desygnatu podstawy słowotwórczej derywatu, jak i do zjawisk przez tę podstawę nienazywanych (1987: 149).

Na podstawie tych spostrzeżeń Volek wyróżnia kilka typów użyć deminutywów. Typ syntetyczny występuje wtedy, gdy stosunek emocjonalny mówiącego jest skierowany do desygnatu podstawy słowotwórczej derywatu deminutywnego. Typ analityczny występuje, gdy bodziec dla nacechowania emocjonalnego jest nazwany przez inną część wypowiedzi niż derywat deminutywny, np. Odnu minutku, milaja (Jedna minutkę $\left(\mathrm{Qt}_{\mathrm{S}}\right) \mathrm{Exc}_{\mathrm{Ev}+}$, kochanie) (1987: 149). Na tym przykładzie widać, że sufiks deminutywny został dodany do podstawy, która z punktu widzenia nacechowania emocjonalnego wyrażonego w tej wypowiedzi jest albo całkowicie, albo częściowo bez znaczenia. Rzeczywisty obiekt emocji stanowi osoba nazwana w wypowiedzi, do której jest ona skierowana. W tym przypadku deminutyw pełni jedynie rolę mediatora służącego wyrażeniu stosunku emocjonalnego. Nawiasy przy oznaczeniu komponentu ilościowego znaczenia wskazują na to, że nie ma on bezpośrednio wpływu na interpretację derywatu, a ma jedynie charakter pomocniczy. Trzeci przypadek to wariant typu analitycznego. Ma on miejsce wtedy, gdy obiekt, do którego mówiący ma pewien stosunek emocjonalny, nie jest w ogóle nazwany w wypowiedzi. Volek przytacza wypowiedź kelnera: - Odnu minutku. - I oficiant ponessja v proxode sredi stolikow (1987: 150) (- Jedna minut$k e ̨\left(\mathrm{Qt}_{\mathrm{S}}\right) \mathrm{Exc}_{\mathrm{Ev}+}-i$ kelner pospieszyt między stolikami). Tu obiektem stosunku emocjonalnego jest adresat, czyli klient, który nie jest nazwany w wypowiedzi. $\mathrm{Z}$ czwartym typem, czyli z typem łączonym, mamy do czynienia, kiedy sufiks deminutywny wyraża stosunek emocjonalny do desygnatu podstawy derywatu, a za jego pośrednictwem - także do adresata wypowiedzi albo do innych obiektów nazwanych w wypowiedzi bądź obecnych tylko sytuacyjnie (1987: 164). Zdrobnienia tego typu występują często w prośbach i ofertach. W przytoczonej 
poniżej wypowiedzi matki o swojej córce stosunek emocjonalny jest skierowany do dziewczynki, mimo wszystko jednak słowo latka nazywa jeden z atrybutów dziecka, czyli wiek:

L. (smeetsja) Da čto, Vera! Ona bol’šaja, ej uže četvertyj godik. Ona stixi rasskazyvaet. L. (laughs): 'What are you saying, Vera! She's big, she's already four years $\left[\left(\mathrm{Qt}_{\mathrm{S}}\right) \mathrm{Exc}_{\mathrm{Ev}}\right]$ old. She recites poetry.' (1987: 171)

L. śmieje się - Co ty, Vera. Ona jest duża, ma już cztery latka $\left[\left(\mathrm{Qt}_{\mathrm{S}}\right) \mathrm{Exc}_{\mathrm{Ev}+}\right]$. Ona recytuje wiersze.

Przypisanie do semantyki komponentów ilościowych i jakościowych deminutywów powoduje, że analiza Volek może być uznana za zgodną z podejściem semantycznym do polisemii. Choć za Grudzińską podano powyżej argumenty, które wskazują na braki tego podejścia, warto zwrócić uwagę na niefortunną z punktu widzenia teoretycznego własność podziału zaproponowanego przez Bronislavę Volek. Otóż oba komponenty semantyczne zdrobnień występują razem lub też osobno. Częste są przykłady, gdy dla konkretnego derywatu trudno bez odwoływania się do kontekstu określić, czy ma tylko jeden komponent znaczeniowy, czy obydwa. Oczywiście występują deminutywa, które inherentnie mają tylko jeden z wymienionych komponentów znaczeniowych, jak słoneczko. Jednak często nie można ustalić, czy dany derywat ma w swoim znaczeniu komponent jakościowy bez uprzedniego zidentyfikowania bodźca do wystąpienia stosunku emocjonalnego. Innymi słowy, nie można określić semantycznego znaczenia deminutywu bez uprzedniej analizy pragmatycznej. Wprawdzie nacechowanie emocjonalne zdrobnień może być inwariantnym znaczeniem semantycznym, jak w przypadku derywatu słoneczko, jednak w wielu innych przypadkach jego wystąpienie jest silnie zależne od nadawcy komunikatu i kontekstu, w którym derywat został użyty, przez co nosi znamiona znaczenia pragmatycznego. Zatem na przykładzie opisu znaczenia deminutywów zaproponowanego przez Volek można zaobserwować krytykowane przez Grudzińską zatarcie podziału między semantyką i pragmatyką, w konsekwencji prowadzące do braku możliwości ustalenia znaczenia słów poza kontekstem.

Jednak nie tylko semantyczne podejście do polisemii prowadzi do niefortunności w opisie znaczeń deminutywnych. Zgodnie z podejściem pragmatycznym słowa mają jedno podstawowe znaczenie semantyczne, zaś to, co zmienne, należy do sfery pragmatyki. Istnieją deminutywa, które mają tylko jeden inwariantny element znaczeniowy - bądź to wskazują na mały rozmiar desygnatu, bądź na stosunek emocjonalny mówiącego. Jednakże, jak zauważa Volek, w przypadku większości zdrobnień ustalenie, czy wskazują na wielkość, czy na nacechowanie emocjonalne, czy oznaczają oba te elementy, dokonywane jest w kontekście. Zatem dla procesu deminutywizacji ustalenie znaczenia inwariantnego staje się problematyczne. Zgodnie z założeniami podejścia pragmatycznego, oba elementy 
znaczeniowe raz spełniałyby warunki, żeby przyporządkować je pragmatyce, a raz można by przyporządkować je semantyce. Takie rozwiązanie również nie jest jednak w pełni satysfakcjonujące.

\section{Deminutywa w morfopragmatyce}

Kolejne podejście opisujące znaczenia zdrobnień zostało przedstawione przez Wolfganga Dresslera i Lavinię Merlini Barbaresi (1994). W książce autorzy analizują właśnie takie afiksy i inne środki morfologiczne, których znaczenie zdaje się przede wszystkim umiejscowione w sferze pragmatycznej. Nie mają one stałego znaczenia semantycznego (stable semantic value) i ich znaczenie często jest trudne do uchwycenia (1994: 1). Szczególnie dużo uwagi autorzy poświęcają deminutywom w języku włoskim i niemieckim.

Oryginalna koncepcja Dresslera i Merlini Barbaresi opiera się na wprowadzonym przez autorów pojęciu morfopragmatyki, czyli pewnego rodzaju zgramatykalizowanej pragmatyki (1994: 52). Morfopragmatyka zajmuje się regularnymi pragmatycznymi efektami regularnych operacji derywacyjnych i fleksyjnych. Jest dziedziną pośrednią pomiędzy semantyką i pragmatyką. W przeciwieństwie do semantyki, morfopragmatyka uwzględnia czynniki pragmatyczne, jak sytuacjach mowna, akty mowy oraz strategie komunikacyjne (speaker-hearer strategies). W przeciwieństwie do pragmatyki, morfopragmatyka bada autonomiczne znaczenia pragmatyczne, przysługujące niektórym operacjom morfologicznym. W swoich badaniach autorzy ustalają, czy operacja morfologiczna podlega autonomicznym ograniczeniom pragmatycznym (autonomous pragmatic constraints), które można przypisać tej operacji jako takiej, a które nie wynikają ani z ograniczeń semantycznych ani z ogólnych reguł pragmatycznych.

Dressler i Merlini Barbaresi podkreślają, że morfopragmatykę należy odróżnić od takich dziedzin jak morfosemantyka, semantyka leksykalna w morfologii oraz pragmatyka leksykalna w morfologii (1994: 55).

Morfosemantyka zajmuje się regularnymi zmianami w denotacji i konotacji słów poddanych operacjom morfologicznym, zachodzącymi niezależnie od znaczenia ich podstaw słowotwórczych. Obszar zainteresowania semantyki leksykalnej w morfologii ogranicza się do badania denotacyjnych i konotacyjnych znaczeń semantycznych przynależnych wyrazom złożonym, szczególnie swoistych zmian w semantyce słów powstałych w wyniku działania operacji morfologicznej. Natomiast pragmatyka leksykalna w morfologii zajmuje się idiosynkratycznymi znaczeniami/efektami pragmatycznymi poszczególnych słów złożonych (1994: 56). Innymi słowy, morfosemantyka i morfopragmatyka zajmują się stałymi zmianami znaczenia, zachodzącymi w wyniku zastosowania reguły morfologicznej, które są niezależne od uczestniczących w tym procesie jednostek leksykalnych. 
Dressler i Merlini Barbaresi poświęcają deminutywom rozdział trzeci swojej książki (1994: 84-414). Ze względu na jego długość, wnioski poczynione przez autorów przedstawimy jedynie skrótowo. Podawane przez nich dane językowe pochodzą z różnego rodzaju źródeł mówionych i pisanych, część przykładów została zaczerpnięta $z$ literatury lub też została utworzona przez samych autorów. Podawane przykłady pochodzą z różnych rejestrów językowych, sytuacji mownych oraz tłumaczeń.

Autorzy dużo uwagi poświęcają zależności pomiędzy znaczeniami morfosemantycznymi i morfopragmatycznymi deminutywów. Skłaniają się ku hipotezie maksymalistycznej (maximalist hypothesis), zgodnie z którą znaczenie denotacyjne [mały] zostaje przypisane morfosemantyce, a wszystko, co pozostaje morfopragmatyce, argumentując, że domniemane konotacje morfosemantyczne dają się wyprowadzić z pragmatyki. W ten sposób stałe konotacje poszczególnych derywatów deminutywnych można jedynie przypisać do semantyki leksykalnej w morfologii jako konotacje zleksykalizowane (1994: 141).

Podejście minimalistyczne, z którym autorzy się nie zgadzają, polega na przypisaniu inwariantnych denotacji i konotacji do semantyki, podczas gdy zmiennymi konotacjami zajmuje się pragmatyka (1994: 141). W ujęciu minimalistycznym użycia morfopragmatyczne deminutywów są wyprowadzane wprost z morfosemantycznego inwariantnego znaczenia denotacyjnego i morfosemantycznych inwariantnych znaczeń konotacyjnych przy zastosowaniu ogólnych strategii pragmatycznych (general pragmatic strategies), bez wprowadzania jakichkolwiek pośrednich inwariantów morfopragmatycznych (1994: 141, 143).

Zgodnie z koncepcją maksymalistyczną, na poziomie morfosemantycznym zdrobnienia przyjmują znaczenie [mały] lub jego alosem [nie-ważny] [non-important], które są przypisywane do poszczególnych słów w wyniku działania operacji morfologicznej. Dressler i Merlini Barbaresi są zdania, że można również wyróżnić autonomiczną cechę pragmatyczną (pragmatic feature) działającą na morfologicznej operacji tworzenia deminutywów. Na poziomie morfopragmatycznym deminutywa przyjmują znaczenie [nie-poważny] [non-serious] (1994: 144). Cecha [nie-poważny] działa na całym akcie mowy. Jest ona m.in. strategią umożliwiającą nadawcy komunikatu obniżenie własnej odpowiedzialności za wykonany akt mowy, innymi słowy - obniżenie własnego zaangażowania w stosunku do jego siły illokucyjnej (1994: 144). Dresseler i Merlini Barbaresi podkreślają, że cecha [nie-poważny] modyfikuje moc illokucyjną (illocutionary strength) przy zachowaniu siły illokucyjnej (illocutionary force), co oznacza, że typ aktu mowy nie ulega zmianie. Wpływ deminutywów na moc illokucyjną jest niewielki (1994: 315). Autorzy twierdzą, że deminutywa modyfikują wszystkie wymiary skalarne siły illokucyjnej poprzez równoczesne ich obniżenie (downgrading). Nawiązują tu do wcześniejszej hipotezy, jakoby deminutywa obniżały jedynie niektóre wymiary skalarne aktów mowy (Bazzanella, Caffi, Sbisà 1991). 
W modelu maksymalistycznym autorzy wyróżniają dwa wymiary: statyczny i dynamiczny. Wymiar statyczny obejmuje sytuację mowną (speech situation), a wymiar dynamiczny wydarzenie mowne (speech event) (1994: 5).

Omawiane przez autorów sytuacje mowne, w których deminutywa są często używane, to sytuacje mowne mające związek z dziećmi (child-centred speech situation), zwierzętami domowymi (pet-centred speech situation) i partnerami w związku uczuciowym (lover-centered speech situation). Wynika to z cechy [nie-poważny], która jest wspólna dla wszystkich tych sytuacji, a także dla deminutywów. W formalnych sytuacjach mownych deminutywa praktycznie nie występują, ponieważ sytuacje te odznaczają się cechą [-nie-poważny]. W pozostałych przypadkach użycie deminutywów jest zależne od stopnia oficjalności bądź nieoficjalności danej sytuacji mownej (1994: 325).

Wymiar dynamiczny obejmuje akty mowy, a także dodatkowe parametry, nazwane czynnikami regulacyjnymi (regulative factors). Analiza aktów mowy Dresslera i Merlini Barbaresi jest mikropragmatyczna. Autorzy opierają się na typologii aktów mowy Searla (Searle, Vanderveken 1985), do Austina odwołują się sporadycznie. Dressler i Merlini Barbaresi skupiają uwagę głównie na użyciu zdrobnień w aktach dyrektywnych, przede wszystkim w prośbach, oraz w asercjach. Pozostałe akty mowy, które podlegają analizie to akty deklaratywne oraz około piętnastu typów aktów ekspresywnych i komisywnych, w tym przeprosiny, podziękowania, obietnice, groźby i oferty. Autorzy omawiają też akty mowy spoza tej typologii - akty erotetyczne, retraktywne i wokatywne. Natomiast czynniki regulacyjne wymieniane przez autorów to m.in.: żartobliwość, emocja, empatia, zażyłość, skromność, umniejszenie, eufemizacja, ironia, sarkazm, czy wybór stylistyczny. Czynniki regulacyjne wpływają na prawdopodobieństwo wystąpienia zdrobnień. Heterogeniczność czynników regulacyjnych wynika z tego, że zostały wyróżnione za pomocą indukcji (Schneider 2003: 51).

Biorąc pod uwagę dużą ogólność inwariantu [nie-poważny] należy podkreślić, że model zaproponowany przez Dresslera i Merlini Barbaresi wymaga od nadawcy dokonania interpretacji czynników i warunków pragmatycznych, a także umożliwia negocjowanie interpretacji i znaczeń z innymi uczestnikami aktu mowy.

Jako ilustracja niech posłuży akt mowy przytoczony przez autorów, pochodzący z języka włoskiego (Dressler, Merlini Barbaresi 1994: 157):

Come vorrei essere nel mio lett-ino!

'How I wish I were in my nice comfy bed!'

Jak bardzo chciałbym być w moim łóżeczku!

Osoba wypowiadająca to zdanie jest dorosła. Mówca jest zmęczony i chciałby się położyć. Dressler i Merlini Barbaresi stwierdzają, że łóżko, czyli desygnat deminutywu, w rzeczywistości wcale nie musi być małe, jest ono jedynie 
przedstawione w ten sposób. Cecha [nie-poważny] działa wprost z sufiksu na akty mowy modyfikując go. Mówca obniża własne zaangażowanie w stosunku do jego siły illokucyjnej. W rezultacie deminutyw wskazuje na to, że mówiący nie myśli poważnie o możliwości położenia się do łóżka (1994: 158). Użycie deminutywu ma za zadanie wskazać na potrzebę osoby wypowiadającej zdanie, żeby znaleźć się w przytulnym, ciepłym i bezpiecznym schronieniu własnego łóżka. Można tę sytuację interpretować jako metaforyczne przywołanie sytuacji mownej dotyczącej dzieci, w której mówca przyjmuje rolę dziecka (1994: 157).

Wyjątkowość podejścia morfopragmatycznego polega na wyszczególnieniu inwariantnej cechy pragmatycznej [nie-poważny], która jest wspólna dla wszystkich deminutywów. Model ten jest zatem różny od obu podejść do polisemii, ponieważ wskazuje na inwarianty i w domenie semantyki, i pragmatyki.

Można zgłosić kilka zastrzeżeń do modelu Dresslera i Merlini Barbaresi, w jednym z artykułów Francisco Santibáñez Sáenz (1999: 182-183) zwraca uwagę na dwa problemy tego podejścia. Pierwszy z nich dotyczy siły eksplanacyjnej cechy [nie-poważny]. Zdaniem autora interpretacja użyć deminutywów w kontekście nie zasadza się na jednej autonomicznej cesze, ale na mechanizmie implikatury, zasadzie relewancji i działaniu procesów konwencjonalizacji. Santibáñez Sáenz uważa, że interpretacja przytoczonego aktu mowy jako komunikującego chęć, żeby położyć się spać, opiera się na wyrażeniu pozytywnego nastawienia emocjonalnego do łóżka, co jest uczynione poprzez dołączenie sufiksu deminutywnego do podstawy słowotwórczej nazywającej ten przedmiot. W kontekście, w którym mówiący nie może rzeczywiście się położyć, jego wypowiedź może być uznana za relewantną tylko wtedy, gdy nie mówi serio. W języku włoskim użycie deminutywów w wypowiedziach informujących o chęci bądź życzeniu jest skonwencjonalizowanym sposobem, żeby wskazać na ich niepoważny wydźwięk. Zatem w tym języku interpretacja implikatury odbywa się automatycznie. W innych językach, żeby zinterpretować wypowiedź jako niepoważną, słuchacz musi dokonać inferencji w oparciu o znaczenie użytych w wypowiedzi słów, a także jej kontekst. Druga wątpliwość związana z podejściem morfopragmatycznym Dresslera i Merlini Barbaresi dotyczy założenia, zgodnie z którym cecha [nie-poważny] działa wprost od sufiksu do aktu mowy. Nie jest jasne, jaki wpływ ma ta cecha na znaczenie wyrazu, do którego dołączono sufiks deminutywny. Wydaje się jednak, że musi zajść jakaś relacja między sufiksem i podstawą słowotwórczą.

\section{Deminutywa w ujęciu formalno-funkcjonalnym Klausa Schneidera}

Klaus Schneider (2003) analizuje zdrobnienia w języku angielskim, przyjmując paradygmat formalno-funkcjonalny Geoffreya Leecha (1983). Paradygmat ten zakłada, że gramatyka, czyli abstrakcyjny formalny system języka, oraz 
pragmatyka są osobnymi, uzupełniającymi się nawzajem obszarami w językoznawstwie. Należy wyjaśnić, że w tym ujęciu pragmatyka obejmuje wszelkie aspekty użycia języka w komunikacji, podczas gdy gramatyka - wszystkie poziomy systemu języka, w tym semantykę. Badanie języka nieodzownie prowadzi do studiowania obu tych dziedzin oraz interakcji między nimi. Zatem własności deminutywów mogą być w pełni poznane, jeżeli zostaną zbadane ich właściwości z obu tych obszarów oraz interakcja, która między nimi zachodzi.

Graf 1 jest przytoczony za Schneiderem. W górnej części diagram przedstawia formalne i funkcjonalne aspekty deminutywów, takie jak ich forma, znaczenie, funkcje w komunikacji i dystrybucja, dolna część - zajmujące się tymi aspektami obszary językoznawstwa. Opis gramatyki deminutywów obejmuje identyfikację markerów deminutywności (diminutive markers) oraz tego, jak są one stosowane w celu tworzenia deminutywów, a także na ustaleniu znaczeń powstałych form. Natomiast opis pragmatyczny zasadza się na ustaleniu funkcji komunikacyjnych deminutywów i ich dystrybucji.

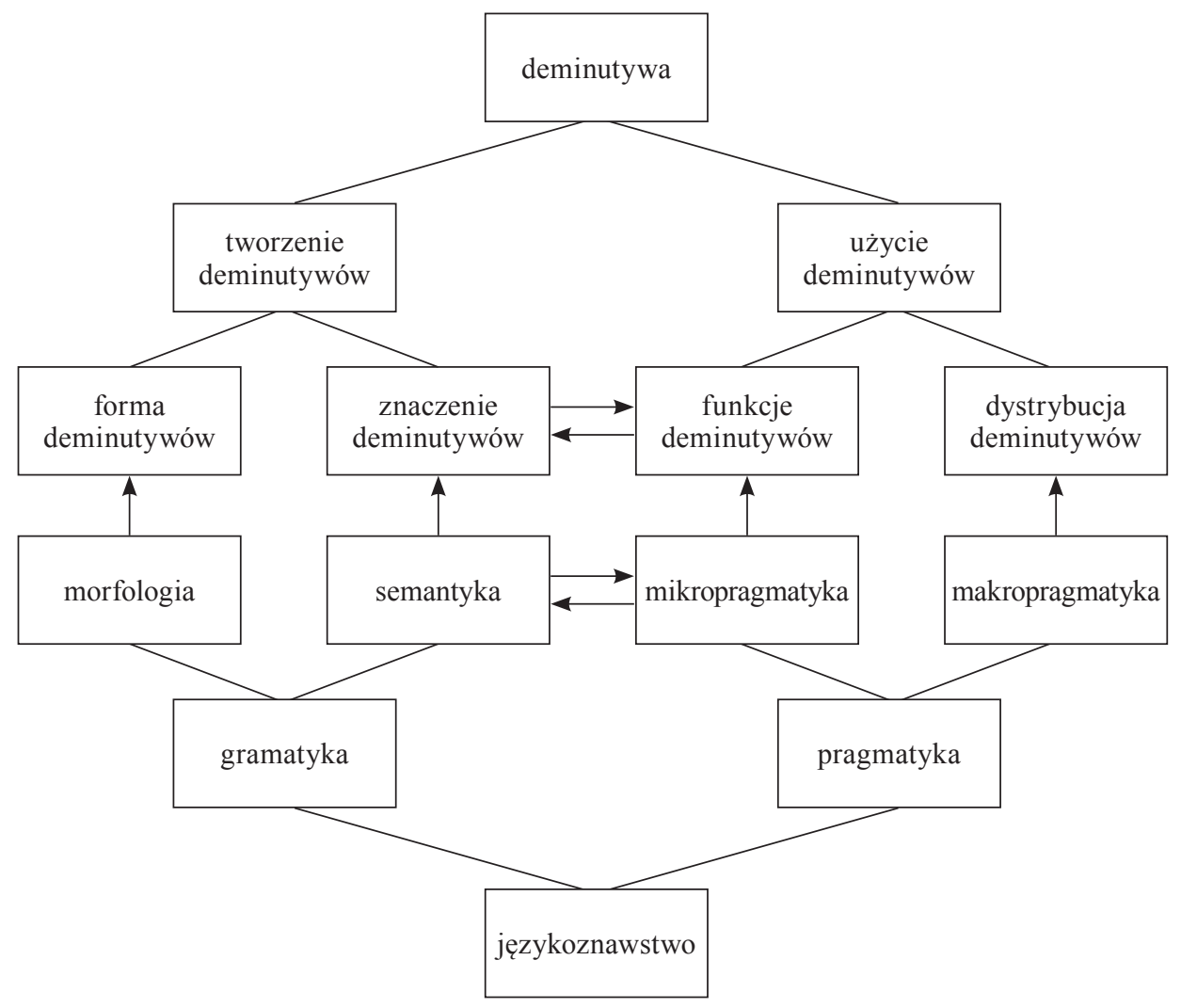

Graf 1. Właściwości deminutywów i odpowiadające im obszary badań językoznawczych (Schneider 2003: 59) 
Często uznaje się, że język angielski praktycznie nie ma deminutywów. Schneider zauważa jednak, że angielski bardzo różni się pod względem słowotwórstwa od języków, w których występuje wiele prototypowych deminutywów, jak język włoski czy języki słowiańskie. Na przykład konwersja (derywacja syntaktyczna), czyli przekształcenie kategorii gramatycznej wyrazu bez zmiany jego formy, jest wyjątkowo częsta w języku angielskim, a np. w języku polskim nie odgrywa większej roli. Kolejnym z przykładów jest stopniowanie przymiotników i przysłówków, które w języku angielskim często jest zjawiskiem analitycznym, tzn. dany przymiotnik bądź przysłówek jest poprzedzony słowami more (bardziej) lub most (najbardziej), natomiast w wielu innych językach, w tym w polskim, jest najczęściej zjawiskiem syntetycznym. Trzeba zatem uwzględnić to, że również deminutywa w języku angielskim mogą różnić się od deminutywów prototypowych. Badanie jedynie derywacji afiksalnej (additive morphology) może nie prowadzić do właściwych wniosków.

Gdy zastosuje się do języka angielskiego podejście funkcjonalne widać, że znaczenie małości w sensie dosłownym i metaforycznym jest wyrażane w języku angielskim nie tylko poprzez afiksację (2003: 76). Schneider dochodzi do wniosku, że zdrobnienia to w większym stopniu kategoria semantyczna (semantic category) niż kategoria słowotwórcza (morphological category). Autor proponuje, żeby wyróżnić deminutywa syntetyczne i analityczne, podobnie jak to się dzieje w przypadku przymiotników i przysłówków wyższych stopni. Deminutywa syntetyczne to formacje o złożonej budowie słowotwórczej, prototypowym przykładem są tu derywaty sufiksalne, jak dog $>$ doggy (piesek), duck > duckling (kaczuszka, kaczątko), pig > piglet (prosiatko, prosiaczek). Deminutywa analityczne to konstrukcje złożone z przymiotnika o znaczeniu małości oraz rzeczownika, np. little house (maty dom, domek), small window (małe okno, okienko). Co ciekawe, w języku angielskim są dwa neutralne stylistycznie przymiotniki mające znaczenie małości small i little. Zwykle uznaje się, że small ma wydźwięk bardziej obiektywny, tzn. z reguły odnosi się jedynie do rozmiaru, natomiast little ma wydźwięk bardziej subiektywny, ponieważ może nieść nacechowanie emocjonalne typowe dla deminutywów syntetycznych w innych językach.

Jeśli chodzi o semantykę zdrobnień, Schneider stwierdza, że nie istnieje inwariantne znaczenie deminutywów, jednak wszystkie znaczenia są ze sobą powiązane i zależne od kontekstu oraz znaczenia podstawy słowotwórczej. Wymienia kilka takich znaczeń: małość (droplet, kropelka), młody wiek/niedorosłość (duckling, kaczuszka, kaczątko) i pozytywny bądź negatywny stosunek emocjonalny (auntie, cioteczka, thieflet, złodziejaszek). Schneider wspomina też o możliwości uznania za deminutywa również czasowników i przymiotników o osłabionym znaczeniu, np. yellow > yellowish (żólty > żóltawy). 
W części poświęconej analizie pragmatycznej Schneider bada deminutywa w codziennych konwersacjach, analizując akty dyrektywne, komisywne, ekspresywne, asercje oraz akty wokatywne. Zauważa, że deminutywa są używane we wszystkich wymienionych typach aktów mowy. Co więcej, typ aktu mowy wpływa na to, jaką funkcję pełnią użyte w nim deminutywa. Należy podkreślić, że rozróżnia on zdrobnienia lokalne i globalne (2003: 230). Deminutywa lokalne służą wyrażeniu stosunku emocjonalnego nadawcy do desygnatu deminutywu, deminutywa globalne modyfikują akt mowy, w którym się pojawiają. Czynniki, które są kluczowe dla użycia i interpretacji zdrobnień to cel illokucyjny (illocutionary point) oraz skala pragmatyczna w rozumieniu Leecha (1983), właściwa dla danego aktu mowy. Co ważne, deminutywa odgrywają niebagatelną rolę jako środek językowy wyrażający grzeczność. Na podstawie zróżnicowanych danych korpusowych Schneider zauważa następujące korelacje między typem aktu mowy, funkcją deminutywu oraz skalą pragmatyczną (2003: 230-231):

Akty dyrektywne: minimalizator wydatków (skala wydatki - korzyści)

Akty komisywne: minimalizator korzyści (skala wydatki - korzyści)

Akty ekspresywne: minimalizator pochwały (skala zarzuty - pochwały)

Asercje: minimalizator pochwały (skala zarzuty - pochwały)

Akty wokatywne: maksymalizator życzliwości (skala niechęć - życzliwość)

Schneider poświęca cały rozdział piąty swojej książki (2003: 138-235) analizie deminutywów w aktach mowy. Powyższe uogólnienie nie oddaje zatem w pełni niuansów użycia deminutywów w codziennych konwersacjach. Zostało jednak przytoczone, żeby unaocznić fakt, że można zauważyć pewne stałe tendencje dotyczące funkcji deminutywów w aktach mowy w języku angielskim. Co ciekawe, w języku polskim również można zaobserwować deminutywa pełniące powyższe funkcje. $Z$ tego względu, mimo że Schneider analizował funkcje deminutywów w aktach mowy w języku angielskim, przytoczone niżej przykłady pochodzą z języka polskiego. Zostały one zaczerpnięte z Narodowego Korpusu Języka Polskiego, ze źródeł pisanych i mówionych.

W dyrektywnych aktach mowy deminutywa służą umniejszeniu kosztu dla słuchacza:

Niech pan nam da minutkę. (NKJP)

W tym akcie mowy nadawca prosi odbiorcę komunikatu o cierpliwość. Poprzez zastosowanie zdrobnień „umniejsza się” długość oczekiwania, a co za tym idzie - kłopotliwość wykonania tego, o co nadawca prosi.

W komisywnych aktach mowy zdrobnienia służą , umniejszeniu” zysku słuchacza. Jako przykład niech posłużą oferty, które odznaczają się tym, że łączą się z kosztem dla nadawcy, a zyskiem dla słuchacza: 
Może papieroska? (NKJP)

Zastosowanie deminutywów jest strategią językową, która polega na „umniejszeniu” ofiarowanego obiektu bądź czynności. Pozwala to słuchaczowi z większą łatwością zaakceptować oferowane dobro bez poczucia bycia zachłannym (2003: 232).

W ekspresywnych aktach mowy Schneider skupia się na komplementach oraz na aktach mowy obrażających adresata. Komplementy służą nawiązaniu i utrzymaniu pozytywnych relacji ze słuchaczem. Schneider zwraca uwagę, że w kulturze europejskiej oszczędne komplementy sprawiają wrażenia bardziej szczerych niż komplementy emfatyczne (2003: 201). Deminutywa w komplementach są tworzone od słów, które odnoszą się do ocenianego obiektu ,umniejszając” go:

Ale masz śliczne kubeczki! (NKJP)

Ze względu na owo ,umniejszenie”, deminutywa w komplementach funkcjonują jako minimalizatory pochwały (praise minimisers).

Deminutywa mogą również służyć jako środek językowy wyrażający niegrzeczność. Obrażając innych, nadawca stosuje deminutywa, żeby podkreślić swoją wyższość i lekceważenie w stosunku do odbiorcy komunikatu, zdrobnienie staje się zatem maksymalizatorem zarzutu (antipathy maximiser):

\section{Rzygaj, chtopczyku, rzygaj. Najlepiej na podtoge, bo mi zlew zapchasz. (NKJP)}

Powyższa wypowiedź jest skierowana do osoby dorosłej. Adresat jest „umniejszony” nie tylko przez zastosowanie deminutywu, ale także przez wybór podstawy słowotwórczej, która zwykle nazywa istoty niedorosłe.

$\mathrm{W}$ asercjach deminutywa zwykle służą jako minimalizatory pochwały ( $p r a-$ ise minimisers). Dzieje się tak np., gdy nadawca mówi o posiadanych przez siebie dobrach materialnych. Deminutywa w takich wypowiedziach mogą być interpretowane jako wyrażające pozytywny stosunek do posiadanego przez siebie dobra, ale też „umniejszają” wartość danego dobra, w ten sposób rozmówca unika chwalenia się:

\footnotetext{
A wiesz, że pierwsze własne mieszkanie zdobyłem po czterdziestce? Przedtem byty wynajęte mieszkania, przeprowadzki, hotele, walizki. Teraz mam domek z paroma kominkami, który kocham. Siedzę przed ogniem, rąbię drewno... (NKJP)
}

W aktach wokatywnych zdrobnienia zwykle pełnią funkcję maksymalizatorów życzliwości (sympathy maximisers). Deminutywa w aktach wokatywnych to przede wszystkim formy adresatywne, w szczególności zdrobniałe imiona, nazwy członków rodziny i zdrobniałe przezwiska, jak Pawełek, Beatka, tatuś, mamusia, thuścioszek. 
Praca Schneidera może być zinterpretowana jako zgodna z semantycznym podejściem do polisemii, ponieważ autor wyróżnia kilka znaczeń semantycznych, które mogą przysługiwać indywidualnym deminutywom oraz stwierdza, że nie istnieje inwariantne znaczenie dla deminutywów. Co więcej, zawsze analizuje znaczenie zdrobnień w kontekście.

Analiza deminutywów w aktach mowy pozwala na zaobserwowanie, że oznaczanie małości i wskazywanie na pozytywny bądź negatywny stosunek mówiącego to tylko niektóre z zastosowań deminutywów, do tego wcale nie najważniejsze. Deminutywa to przede wszystkim narzędzia językowe, których funkcje przynależą do sfery pragmatyki, mające duże znaczenie jako środki językowe służące do wyrażania uprzejmości bądź nieuprzejmości.

\section{Wnioski}

Pomimo teoretycznych trudności związanych z semantycznym podejściem do polisemii, dominującą $\mathrm{w}$ literaturze tendencją jest semantyczne podejście do opisu znaczeń deminutywnych. Dzieje się tak w pracach Bronislavy Volek i Klausa Schneidera, natomiast praca Dresslera i Merlini Barbaresi jest opracowaniem autorskim i nie wpisuje się ani w podejście semantyczne, ani pragmatycze podejście do polisemii. Co ciekawe, i u Volek, i u Schneidera nacechowanie emocjonalne zostało potraktowane jako znaczenie semantyczne. Brak podejść pragmatycznych opisujących znaczenie deminutywów można wytłumaczyć niemożnością znalezienia inwariantów znaczeniowych dla procesu deminutywizacji.

Deminutywa pełnią w komunikacji przede wszystkim różne funkcje pragmatyczne. Studium Klausa Schneidera może posłużyć jako tego dobitny dowód, ale jest to wyraźnie widoczne również w opracowaniach Volek oraz Dresslera i Merlini Barbaresi, jako że deminutywa są w tych pracach zawsze analizowane $\mathrm{i}$ interpretowane $\mathrm{w}$ kontekście. $\mathrm{Z}$ uwagi na brak inwariantów po stronie semantyki dla procesu deminutywizacji oraz wielość funkcji deminutywnych w komunikacji można stwierdzić, że deminutywa stanowią kategorię na pograniczu semantyki i pragmatyki. Mogą zatem posłużyć jako przykład środków językowych stanowiących argument za tym, żeby nie przeprowadzać ostrego podziału między semantyką i pragmatyką.

\section{Bibliografia}

Bazzanella C., C. Caffi, M. Sbisà. 1991. "Scalar dimensions of illocutionary force”, [w:] I. Ž. Žagar (ed.), Speech acts: fiction or reality?, 63-76.

Dressler, W. U., L. Merlini Barbaresi. 1994. Morphopragmatics. Diminutives and intensifiers in Italian, German, and other languages, Berlin-New York: Mouton de Gruyter. 
Geeraerts, D. 1993. "Vagueness's puzzles, polysemy's vagaries”, Cognitive Linguistics 4 (3), 223-272.

Grudzińska, J. 2011. Polysemy: an argument against the semantic account, „Kwartalnik Neofilologiczny" 3, 273-282.

Leech, G. 1983. Principles of pragmatics, London: Longman.

[NKJP] Narodowy Korpus Języka Polskiego, http://nkjp.pl/ [dostęp: 30.09.2014].

Santibáñez Sáenz, F. 1999. "Conceptual interaction and Spanish diminutives", Cuadernos de investigación filológica 25, 173-190.

Schneider, K. P. 2003. Diminutives in English, Tübingen: Max Niemeyer Verlag.

Searle, J., D. Vanderveken. 1985. Foundations of illocutionary logic, Cambridge, England: Cambridge University Press.

Volek, B. 1987. Emotive signs in language and semantic functioning of derived nouns in Russian, Amsterdam: John Benjamins.

Volek, B. 1990. "Emotive Semantics and Semiotics”, Grazer Linguistische Studien 33/34, 327-347.

Žagar, I. Ž. (ed.). 1991. Speech acts: fiction or reality?, Ljubljana: Institute for Social Sciences. 